\title{
Adaptation of the land agricultural suitability evaluation system to high-altitude vineyards
}

\author{
Adaptación del Sistema de Evaluación de la Aptitud Agrícola de las Tierras \\ a los Viñedos de Altura
}

Denilson Dortzbach ${ }^{1}$; Arcângelo Loss²; Ludmila Nascimento Machado; Marcos Gervasio Pereira; Lúcia Helena Cunha dos Anjos ${ }^{5}$

\begin{tabular}{l}
\hline \multicolumn{1}{c}{ ARTICLE DATA } \\
\hline 1 Researcher, Ph.D., Empresa de Pesquisa Agropecuária e \\
Extensão Rural de Santa Catarina, Santa Catarina, Brazil, \\
denilson@epagri.sc.govbr \\
$2 \quad \begin{array}{l}\text { Professor, Ph.D., Universidade Federal de Santa Catarina, } \\
\text { Santa Catarina, Brazil. arcangelo.loss@ufsc.br }\end{array}$ \\
3 Engenheira Agrônoma, Universidade Federal de Santa \\
Catarina, Santa Catarina, Brazil, luddmachado@hotmail. \\
com \\
$4 \quad$ Professor, Ph.D., Universidade Federal Rural do \\
Rio de Janeiro, Seropédica, Rio de Janeiro, Brazil, \\
mgervasiopereira01@gmail.com \\
5 Professor, Ph.D., Universidade Federal Rural do Rio de \\
Janeiro, Seropédica, Rio de Janeiro, Brazil, lanjosrural@ \\
gmail.com \\
\hline
\end{tabular}

Cite: Dortzbach, D.; Loss, A.; Machado, L.; Pereira, G.; Anjos, L. (2019). Adaptation of the Land Agricultural Suitability Evaluation System to High-Altitude Vineyards. Revista de Ciencias Agrícolas. 36(2): 58-73. doi: https://doi. org/10.22267/rcia.193602.118

Received: June 262019.

Accepted: December 152019.

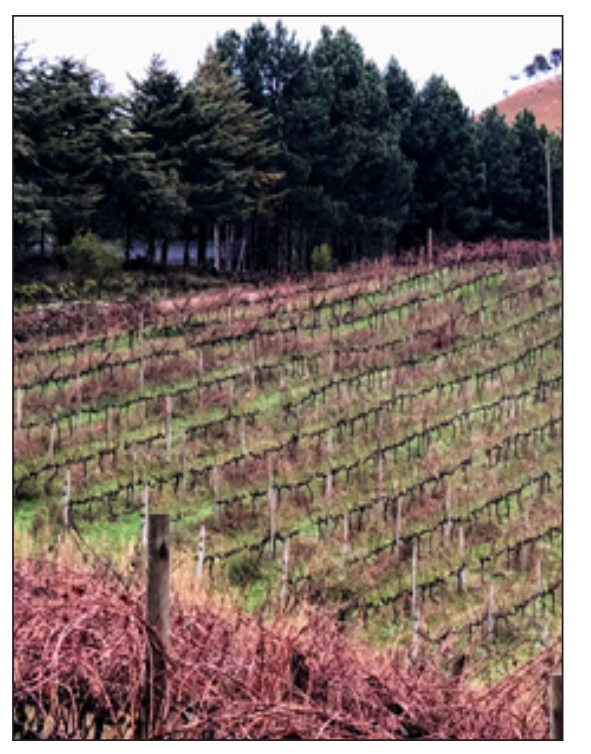

ABSTRACT

Adequate information on agricultural land suitability for viticulture are important for the expansion of the activity in wine producing regions, as the state of Santa Catarina, Brazil. This information contributes to improve the efficiency of evaluations, with the inclusion of different management levels for the crop and redefinition of limiting levels of agricultural land conditions. In this context, the objective of this work was to adapt the Land Agricultural Suitability Evaluation System (LASES) to grapevine crops grown in highaltitude regions in Santa Catarina. The LASES was modified based on the crop demands and managements, proposing the incorporation, removal, adjust and update of parameters used in the LASES. The limiting factors considered were topography, fertility, water excess or oxygen deficiency, susceptibility to erosion, impediments to meccanization, and soil effective depth. These traits were based on data of bibliographic surveys and five limiting levels were attributed to them: null, mild, moderate, strong, and very strong. Agricultural suitability classes like good, regular, restrictive and inapt resulted from the interaction between agricultural conditions and management levels of viticulture producers, and later, a suitability guide table was developed. The adaptation of the LASES to grapevine crops grown in high-altitude conditions in Santa Catarina incorporate and adjust local aspects that are important for the grapevine production system. Thus, it is an important tool for decision making when implementing new vineyards and contributes to a possible increase of this activity in the region.

Keywords: viticulture; soil effective depth; land use; topography; suitability guide table.

\section{RESUMEN}

La información adecuada sobre la idoneidad de las tierras agrícolas para la viticultura es importante para la expansión de la actividad en las regiones productoras de vino, como el estado de Santa Catarina, Brasil. Esta información contribuye a mejorar la eficiencia de las evaluaciones, con la inclusión de diferentes niveles de gestión para el cultivo y la redefinición de los niveles límite de las condiciones de las tierras agrícolas. En este contexto, el objetivo de este trabajo fue adaptar el Sistema de Evaluación de la Aptitud Agrícola de las Tierras (SAAAT) a los cultivos de vid que se producen en las regiones de gran 
altitud de Santa Catarina. El SAAAT se modificó en función de las demandas y las gestiones de los cultivos, proponiendo la incorporación, eliminación, ajuste y actualización de los parámetros utilizados en el SAAAT. Los factores limitantes considerados fueron la topografía, la fertilidad, el exceso de agua o la deficiencia de oxígeno, la susceptibilidad a la erosión, los impedimentos a la meccanización y la profundidad efectiva del suelo. Estos rasgos se basaban en datos de estudios bibliográficos y se les atribuyeron cinco niveles limitantes: nulo, leve, moderado, fuerte y muy fuerte. Las clases de idoneidad agrícola como buena, regular, restrictiva e inapropiada resultaron de la interacción entre las condiciones agrícolas y los niveles de gestión de los productores de viticultura y posteriormente se elaboró un cuadro guía de idoneidad. La adaptación del SAAAT a los cultivos de vid que se realizan en condiciones de gran altitud en Santa Catarina incorporan y ajustan aspectos locales que son importantes para el sistema de producción de la vid. Por lo tanto, es una herramienta importante para la toma de decisiones en la implantación de nuevos viñedos y contribuye a un posible aumento de esta actividad en la región.

Palabras clave: viticultura; profundidad efectiva del suelo; uso de la tierra; topografía; tabla guía de idoneidad.

\section{INTRODUCTION}

Small rural properties in the state of Santa Catarina, Brazil, develop activities that allow high economic returns, considering the strong limitations of the available area for agricultural production. Viticulture has shown to be a viable economical alternative for these properties, whose traditional crops do not ensure their sustainability. Moreover, advances in viticulture and viniculture in search for quality, in detriment of quantity of production, have increased the development of varietal wines, which also changed the profile of many producers, since some of them are currently entrepreneurs in other sectors and liberal professionals (Rigon et al., 2006).

Thus, the importantquestion in the wineproduction chain is how to find areas with potential for the implementation of new vineyards, since the costs for their establishing and maintenance are high. Thus, producers need adequate information on the suitability of lands to assist their decision making. Moreover, the underuse of lands with grapevine production in non-favorable areas to this crop can increase production costs and even decrease the quality of wines produced in them. These aspects denote the importance of using a land agricultural suitability evaluation system adapted to this crop and its management.
Each crop has different responses to limitations due to deficiency of natural soil fertility, need for water, or other agricultural condition; thus, a suitability evaluation by crop would reach more effective results for agricultural production (Ribeiro, 2007). According to Vasconcelos et al. (2013), although the conception of the agricultural suitability methodology had been developed to interpret general surveys, it is elastic enough to allow adjusts to specific demands. For example, Araújo and Assad (2001) used the Land Agricultural Suitability Evaluation System (LASES) to propose a pedoclimatic zoning methodology for rainfed rice in the state of Goiás and in the Federal District, in Brazil.

The LASES present some advantages for the adaptation to specific conditions of a crop, including: a) recognition at national level; b) consideration of different management levels as a function of characteristics of farmers; c) possibility of adjust and updating of new information; d) possibility of adaptations and applications in different scales of land mapping; e) consideration of the viability of decreasing limitations by using capital and technology, thus distinguishing the producers by their potential of investment in agricultural practices. 
Thus, the application of the LASES adapted to the grapevine crops and to the high-altitude production conditions would contribute to improve the efficiency of the evaluation due to the inclusion of different management levels to the crop and redefinition of limitation levels of land agricultural conditions.

In this context, the objective of this work was to adapt the LASES described by Ramalho Filho and Beek (1995) to grapevine crops grown in highaltitude regions in the state of Santa Catarina, Brazil. Therefore, the LASES was modified based on the crop demands and managements, proposing the incorporation, removal, adjust, and update of traits used in the LASES, especially the management levels, limiting factors, and suitability guide table.

\section{MATERIAL AND METHODS}

The implementation of the Land Agricultural Suitability Evaluation System (LASES) for grapevine crops in high-altitude regions was done using the method described by Ramalho Filho and Beek (1995), with modifications based on the crop demands and managements, considering the incorporation, removal, adjust, and update of traits and criteria used in the LASES.

Modifications were done in management levels and land agricultural conditions, stablishing values or ranges for all traits considered in the evaluation, using those presented by Pereira and Lombardi Neto (2004) as reference. The basis was the election of indicators with significance for the crop in high-altitude conditions, thus establishing different criteria to evaluate the land suitability.

Thus, some new traits were introduced and some of them were combined in the evaluations. Information found in bibliographic surveys on grape production were used, and five limiting levels were determined: null, mild, moderate, strong, and very strong.

The limiting factors were determined as follows:

Topographic factors. Evaluated based on three landscape components: altitude, slope orientation, and slope steepness.

The altitude level evaluation considered the information described in the regulation of the collective brand Acavitis of the Association of Producers of High-Altitude Fine Wine of Santa Catarina, which limits the minimum altitude for vineyards in $900 \mathrm{~m}$ (Santos et al., 2018). The slope orientation was based on Acharya and Yang (2015), adapted to south hemisphere conditions. The slope steepness was based on the classes proposed by Jones et al. (2004).

Soil fertility factor. The interpretation of soil fertility levels was done through the combination of the edaphic attributes: base saturation (Sarmento et al., 2011) and phosphorus (Vieira et al., 2013) and potassium (Lanyon et al., 2004) contents.

Water excess or oxygen deficiency. This factor was established based on draining classes (Embrapa, 2013), with adaptations in the LASES original methodology (Ramalho Filho and Beek, 1995).

Susceptibility to erosion. The erodibility, factor $\mathrm{K}$ (Giboshi et al., 2006), and slope classes were considered for the establishing of limiting levels, according to Pereira and Lombardi Neto (2004).

Impediments to mechanization. The adaptation done by Pereira and Lombardi Neto (2004) was considered. It uses the combination between the stoniness and rockiness and slope steepness. 
Effective soil depth. It was based on the grapevine crop demands, mainly related to the root system, which seldom exceed $1.20 \mathrm{~m}, 90 \%$ of which distributed in the first $0.60 \mathrm{~m}$ depth. Moreover, the largest part of roots responsible for nutrient absorption are between 0.20 and $0.60 \mathrm{~m}$ depth (Sarmento et al., 2011).

The agricultural suitability classes used were the same of the LASES. These are good, regular, restrict, and inapt. However, these definitions result from interactions between agricultural conditions and management levels of viticulture in high-altitude environments in the state of Santa Catarina. The guide table described in the LASES was also adjusted. It constituted the general guidance for the land agricultural suitability classification as a function of levels of limiting factors related to management and viability for improvement.

\section{RESULTS AND DISCUSSION}

The first change on the Land Agricultural Suitability Evaluation System (LASES) for the adaptation of the system to grapevine crops in the state of Santa Catarina was that crop implementation and maintenance costs excluded level A producers from this land use and, thus, only B and C management levels were considered as producer profiles.

\section{Management levels}

Management B - Viticulture. This management level is composed by small grape producers, family farmers whose wine is produced outside the property. It is based on agricultural practices with medium technological level, characterized by little capital investments and use of research results for management, and improvement and conservation of land and crop conditions. When mechanization is used in this management level, it is not intensive and restrict to simple soil preparation and management practices. Technical assistance is received from public institutions.

Management C - Viticulture-Viniculture. Producers that did not fit as family farmers. Entrepreneurs from other sectors, liberal professionals, and large-scale producers that demand external labor. Complex management practices are adopted to optimize profits and maximize crop yields, with intense use of inputs, for example, soil conditioners and fertilizers, improved varieties, and products to control pests and diseases; and dependence on mechanization. Technical assistance is private, with additional support of public institutions.

Limiting factors. The LASES establishes five limiting factors to evaluate agricultural land conditions: soil fertility deficiency, water deficiency, excess water or oxygen deficiency, susceptibility to erosion, and impediments to mechanization. The present study considered six limiting factors: topography, soil fertility, excess water or oxygen deficiency, susceptibility to erosion, impediments to mechanization, and soil effective depth. All these factors were modified and adjusted for grapevine crops.

Topography. Among the topographic elements that influence the cultivation of the vine are altitude, slope orientation, and slope steepness. The altitude exerts an important thermal effect in viticulture, where every 100 meters of elevation there is a decrease of $0.6^{\circ} \mathrm{C}$ in temperature mean air (Tonietto and Mandelli, 2003). In relation to the slope orientation, those facing the sun dry faster than those facing the opposite side, which is a very important factor in regions with cold weather (White, 2003). According to White (2003), on the slopes soil drainage is generally better than on flat terrain or valley bottoms. And the slope steepness conditions of the land also influence insolation (Tonietto and Mandelli, 2003). For these authors, 
the situations of high slope of the terrain are not recommended, either due to the risk of erosion or the difficulty of mechanization that occurs on slopes with a slope greater than $20 \%$.

Altitude. The mean altitude of the recorded vineyards in the state of Santa Catarina, Brazil, was $1.136 \mathrm{~m}$ up to 2013 , the lowest at $675 \mathrm{~m}$ and the highest at $1.452 \mathrm{~m}$ (Vianna et al., 2016). Most planted area (45.43\%) was within the 1.201 to $1.300 \mathrm{~m}$ range. High altitudes affect night temperatures at harvest, resulting in a more complete phenolic maturation and, thus, better product quality. The soils found in this high-altitude environment in Santa Catarina present, in general, low $\mathrm{pH}$, and high aluminum and organic matter contents (Dortzbach, 2016). These characteristics determine the typicality of the produced wines.

Increases in altitude tend to decrease dry air temperatures at the proportion of $1^{\circ} \mathrm{C}$ every $100 \mathrm{~m}$ (Pajewski et al., 2018). This can be attenuated by increases in solar radiation, warmer soil surfaces, and low wind speed and cold and hot air circulation.

Jones et al. (2004) conducted a survey of land use capacity in a region of Umpqua Valley origin, in Oregon, USA, and found that the local topography and soil are important to grapevine growth and grape quality, with interactive effects with climate elements. According to these authors, the topographic factors that most affect the climate include altitude, slope, and hill aspects. The altitude used as ideal for grapevine crops in the study area were 120 to $240 \mathrm{~m}$.

Slope orientation. The plant row directional orientation is important to obtain quality products. Initially, the local relief of the vineyard should be considered, avoiding rows in steep slope orientations. The north-south orientation tend to be more favorable in viticulture-viniculture regions in Brazil, since it provides a higher exposition to solar radiation in both lateral sides of the rows, mainly in times of mild temperatures (Santos, 2006).

Grape production for fine wine production is favored by high solar radiation availability (Santos et al., 2011). Solar radiation availability to grapevine crops is related to the positions of the Sun throughout the day, according to the angle of incidence of solar rays (Cardoso et al., 2010). In the south hemisphere, slopes oriented to the Equator receive more solar radiation. And it affects thermal and water regimes of the plant-soil system, as well soil properties because of changes in soil moisture and vegetation. According to Valeriano (2008), this traits should be considered to plan agricultural activities, distribution of crops, and harvest forecast and planning. Solar radiation also affects rainfall distribution at regional scale. Moreover, slope orientation can form microclimates, when the area receives more radiation, rainfall, or dust deposits. Spayd et al. (2002) evaluated grapevine rows of variety Merlot with north-south orientation, in Washington, USA, and found that fruits on the east side, which received solar radiation only in the morning period, had higher anthocyanin contents than those in the west side.

Vineyards in Santa Catarina (Vianna et al., 2016) are currently preferentially oriented to the North (N, NE, and NW), represented by 194.1 ha (58.41\%); followed by those oriented to the West (W, SW), represented by 75.5ha (22.73\%); East (E, SE), represented by 45.3 ha $(13.65 \%)$; and South, represented by 17.3 ha (5.22\%).

Slope. Land relief is important to recognizing patterns in the spatial distribution of soil properties. According to Vianna et al. (2016) and using the classification of Uberti et al. (1991), most high-altitude vineyards in Santa Catarina 
are on lands with slightly wavy relief, with slopes between 3 and 8\% (39.38\%), followed by wavy relief, with slopes between 8 and 20\% (37.21\%).

Considering the predominant wavy and strongly wavy relief conditions in many regions of the state of Santa Catarina, the classes proposed by Jones et al. (2004) were adopted, which consider less restrictive values. Table 1 shows the adequate slope values for wine production in Santa Catarina, which can be applied to other high-altitude wine producing regions.

Adequate slope classes according to the crop demands is essential. Plain relief are favorable to mechanization and reduce risks of soil losses by erosion. However, grapevine does not grow in soaked or poorly drained soils, thus these areas present other physical restrictions for the crop development.

Elsheikh et al. (2013) used the Agriculture Land Suitability Evaluator (ALSE) system to support decision and planning of tropical and subtropical crops and presented slope classes for grape production with values of 0 to $6 \%$ as adequate,
6 to $12 \%$ as moderate, 12 to $20 \%$ as marginally adequate, 20 to $25 \%$ as inadequate by economic reasons, and above $25 \%$ as unsustainable for physical reasons. This confirms the importance of modifications according to the local conditions and crop demands, regardless of the evaluation system used.

Soil fertility. Soil chemical characteristics affect the grapevine development. The soil $\mathrm{pH}$ and nutrient availability are the most important chemical characteristics (Univibra, 2015). Considering that soils of grape producing regions in Santa Catarina are naturally acidic, soil acidity correction with application of limestone is a technic associated to both managements level $\mathrm{B}$ and $\mathrm{C}$. Thus, soil acidity is not considered a limiting factor for agricultural suitability, since its correction is a practice inherent to the crop production system in the state.

Regarding the grapevine yield, it depends directly on the soil nutrient supply capacity, which determines the productive performance (Univibra, 2015).

Table 1. Limiting levels for altitude classes, aspect, and slope steepness proposed for the land agricultural suitability evaluation system for grapevine crops in high-altitude regions in Santa Catarina, Brazil.

\begin{tabular}{|c|c|c|c|}
\hline \multirow{2}{*}{ Limiting level } & \multicolumn{3}{|c|}{ Topographic factors } \\
\hline & Altitude (m) & Aspect & $\begin{array}{c}\text { Slope steepness } \\
(\%)\end{array}$ \\
\hline Null & $900-1500$ & $\begin{array}{c}\mathrm{N}\left(337.5^{\circ}-22.5^{\circ}\right) . \mathrm{NW}\left(292.5^{\circ}-337.5^{\circ}\right) \\
\mathrm{NE}\left(22.5^{\circ}-67.5^{\circ}\right)\end{array}$ & 5 to 15 \\
\hline Mild & $800-900$ & $\mathrm{~W}\left(247.5^{\circ}-292.5^{\circ}\right)$ & 15 to 20 \\
\hline Moderate & $700-800$ & $\mathrm{E}\left(67.5^{\circ}-112.5^{\circ}\right)$ & 1 to 5 and 20 to 25 \\
\hline Strong & $600-700$ & $\operatorname{SW}\left(202.5^{\circ}-247.5^{\circ}\right) . \operatorname{SE}\left(112.5^{\circ}-157.5^{\circ}\right)$ & 0 to 1 \\
\hline Very strong & $<600$ & $\mathrm{~S}\left(157.5^{\circ}-202.5^{\circ}\right)$ & $>\mathbf{3 0}$ \\
\hline
\end{tabular}


Soil base saturation. Regarding the soil natural fertility, most soils in grape producing regions in Santa Catarina present low or very low base saturation. Thus, these areas require high rates of soil amendments and fertilizers due to their high organic matter and exchangeable aluminum contents and low nutrient availability. However, this is an intrinsic factor of these soils. Considering the LASES criteria, which establishes as a suitable soil fertility, soils with high base saturation, most high-altitude lands would be restrict or inapt for grape production. However, considering the typicity of the wine produced in this region and peculiarities of grapevine, soil base saturation was adjusted for the region (Table 2).

Few authors do not use soil fertility as land suitability classification criterion, although adopting different parameters. Rasheed and Venugopal (2009) evaluated land suitability for sugarcane crops in India using only climatic parameters and soil physical characteristics. Chagas et al. (2006) evaluated the soil fertility in the western Santa Catarina using the criteria: cation exchange capacity, base saturation, aluminum saturation, and soil texture.

Phosphorus. High-altitude soils in the state of Santa Catarina naturally present nutritional limitations, and phosphorus is the most limiting macronutrient, whose application to the soil is required for the crop to express its maximum productive potential.

Soil fertilization is a common practice of grape producers. However, indicators of need for soil fertilization are not well defined for the state, making soil fertilization recommendation an empirical activity. This generates insecurity on producers (management level B), who end up dependent on recommendations originated from fertilizer sellers, often based on commercial criteria. Therefore, most producers apply fertilizer rates above the crop demands, causing economic losses, hindering the crop production and the environment, since excess fertilizers unbalance soil and plant nutrient contents. Therefore, phosphorus is used as an important parameter to the evaluation system; its classes are presented in Table 2.

Very low and very high phosphorus contents can cause problems to grape production. This nutrient is important for the formation of the canopy, fruiting, root development. It favors wort fermentation (Souza, 1996) and strengthen the aroma and flavor of wines (Regina et al., 2006). González (2005) evaluated the effect of

Table 2. Limiting levels for classes of soil base saturation, phosphorus and potassium contents proposed for the land agricultural suitability evaluation system for grapevine crops in high-altitude regions in Santa Catarina, Brazil.

\begin{tabular}{|c|c|c|c|}
\hline \multirow[b]{2}{*}{ Limiting level } & \multicolumn{3}{|c|}{ Soil chemical factors } \\
\hline & $\begin{array}{c}\text { Base } \\
\text { saturation }\end{array}$ & $\begin{array}{l}\text { Phosphorus } \\
\text { (mg dm } \\
\text { (m) }\end{array}$ & $\begin{array}{c}\text { Potassium } \\
\left(\mathrm{mg} \mathrm{dm}^{-3}\right)\end{array}$ \\
\hline Null & $10-35$ & $13-30$ & $100-250$ \\
\hline Mild & $36-50$ & $30-60$ & $51-100$ \\
\hline Moderate & $51-75$ & $6-12$ & $250-350$ \\
\hline Strong/Very strong & $<10 \mathrm{e}>76$ & $0-5$ e $>60$ & $\leq 50>350$ \\
\hline
\end{tabular}

${ }^{1}$ Mehlich 1 Extractor; ${ }^{2}$ Method of analysis (Embrapa, 1997). 
edaphoclimatic factors on Cabernet Sauvignon grape and wines of different grape producing regions in the state of Rio Grande do Sul, Brazil, and found great variation between vineyards, with phosphorus concentrations varying from 4.3 to $53 \mathrm{mg} \mathrm{dm}^{-3}$ and potassium from 78 to $254 \mathrm{mg} \mathrm{dm}^{-3}$.

Potassium. Potassium is other important macronutrient for grapevine crops. It is accumulated in the berries during the maturation stage (Mafra et al., 2011) and increases the resistance to droughts, low temperatures, diseases, and pests (Souza, 1996). Potassium increases the grapevine yield and affect the initial process of wort fermentation, improving the wine aroma and flavor (Regina et al., 2006). The grape maturation process is characterized by significant increases in potassium contents in the berries and increases in berry weight.

Excess potassium in the soil can decrease sugar concentration in the berries, increase the wort $\mathrm{pH}$ and, consequently, result in a low-quality wine (Mota et al., 2006). Moreover, it can competitively inhibit $\mathrm{N}, \mathrm{Mg}$, and $\mathrm{Ca}$ absorptions.

The potassium content classes adjusted to grapevine crops in high-altitude regions of Santa Catarina are presented in Table 2. Excess potassium was considered as a negative factor, since many soils of the region have naturally high potassium contents.

Excess water or oxygen deficiency. Grapevine development is better in well-drained soils. This is one of the most important soil physical attributes for the health of grapevines, which is related to the internal water drainage or soil permeability. Table 3 shows the limiting levels and classes related to the excess water factor.
Table 3. Limiting levels for classes of drainage, proposed for the land agricultural suitability evaluation system for grapevine crops in highaltitude regions in Santa Catarina, Brazil.

\begin{tabular}{lc}
\hline Limiting level & Drainage classes \\
\hline Null & Excessively; Strongly; \\
& Pronouncedly; Well drained \\
Mild & Moderately drained \\
Moderate & Imperfectly drained \\
Strong & Poorly drained \\
Very strong & Very poorly drained \\
\hline
\end{tabular}

The occurrence of rotten roots and fungi and other pathogenic organisms that hinder the grapevine root system development increases in poorly drained soils (Wolf and Boyer, 2003). Contrastingly, water availability is the variable that have the greatest effect on the grape composition (Leeuwen et al., 2009).

Chen (2011) used a geographical information system to define adequate regions for viticulture/ viniculture in the state of Nebraska, USA, attributing weights of 0 to 10 for selected variables of climate, soil and relief. And according these authors, soil drainage and lowest winter temperature were the most important factors, with weight 10. Occurrence of rime had weight 9. Degree-days had weight 8. Land slope steepness and orientation had weights 6 and 5, respectively; and $\mathrm{pH}$ values and organic matter contents had weight 4 .

Susceptibility to erosion. The susceptibility to erosion factor is related to the easiness of soil removal by the action of winds or waters. This is an important factor because soils with low susceptibility to erosion tend the have lower soil and nutrient losses, favoring management practices and soil conservation, thus lowering production costs and environmental impacts associated to soil erosion. 
Some soils are more eroded that others, even under the same slope, rainfall, plant cover, and management practice conditions. This difference is due to the nature of the soil, which is termed erodibility (factor K) (Eduardo et al., 2013). The susceptibility to erosion factor was evaluated based on two parameters, erodibility (Table 4) and slope steepness (Table 5).

Impediments to mechanization. Mechanization is an important factor for grape production, whose use increases every year by producers at management levels $\mathrm{B}$ and $\mathrm{C}$, to optimize the grapevine cultural practices. The limiting levels of impediments to mechanization is evaluated considering the combination of stoniness and rockiness and slope steepness (Tables 6 and Table 7 ), due to the importance of these attributes to the land use and management.

Table 4. Limiting levels for soil erodibility, proposed for the land agricultural suitability evaluation system for grapevine crops in high-altitude regions in Santa Catarina, Brazil.

\begin{tabular}{lc}
\hline \multicolumn{1}{c}{ Limiting level } & Erodibility $\left(\mathbf{M g ~ h ~} \mathbf{~ M}^{-\mathbf{1}} \mathbf{~ m m}^{-\mathbf{1}} \mathbf{)}\right.$ \\
\hline $0=$ Null & $<0.010$ \\
1= Mild & 0.010 a 0.020 \\
2= Moderate & 0.020 a 0.030 \\
3= Strong & 0.030 a 0.040 \\
4= Very strong & $>0.040$ \\
\hline
\end{tabular}

Table 5. Limiting levels for susceptibility to erosion (slope steepness $\times$ erodibility), proposed for the land agricultural suitability evaluation system for grapevine crops in high-altitude regions in Santa Catarina, Brazil.

\begin{tabular}{|c|c|c|c|c|c|c|c|}
\hline \multirow{2}{*}{\multicolumn{2}{|c|}{ Slope }} & \multirow{3}{*}{$\begin{array}{c}\text { Relief } \\
\text { Type }\end{array}$} & \multicolumn{5}{|c|}{ Erodibility $\left(\mathrm{Mg} \mathrm{h} \mathrm{MJ}^{-1} \mathrm{~mm}^{-1}\right)$} \\
\hline & & & Null & Mild & Moderate & Strong & Very strong \\
\hline \multirow{2}{*}{$\frac{\text { Class }}{\mathrm{A}}$} & \multirow{2}{*}{$\begin{array}{c}\% \\
0-3\end{array}$} & & \multicolumn{5}{|c|}{ Limiting level $^{1}$} \\
\hline & & Plain & 0 & 1 & 1 & 2 & 3 \\
\hline $\mathrm{B}$ & $3-8$ & Slightly wavy & 1 & 1 & 2 & 3 & 4 \\
\hline $\mathrm{C}$ & $8-13$ & Moderately wavy & 2 & 3 & 3 & 4 & 4 \\
\hline $\mathrm{D}$ & $13-20$ & Wavy & 3 & 4 & 4 & 4 & 4 \\
\hline $\mathrm{E}$ & $20-45$ & Strongly wavy & 4 & 4 & 4 & 4 & 4 \\
\hline $\mathrm{F}$ & $>45$ & Mountain or Escarpment & 4 & 4 & 4 & 4 & 4 \\
\hline
\end{tabular}

Limiting Levels: 0 = Null; 1 = Mild; 2 = Moderate; 3 = Strong; 4 = Very Strong. 
Table 6. Limiting levels for stoniness and rockiness, proposed for the land agricultural suitability evaluation system for grapevine crops in high-altitude regions in Santa Catarina, Brazil.

\begin{tabular}{lcc}
\hline \multicolumn{1}{c}{ Limiting level } & Rockiness (\%) & Stoniness (\%) \\
\hline 0 = Null & Without rocks & Without stones \\
$1=$ Mild & $<2$ & $<15$ \\
2 = Moderate & 2 a 15 & 15 a 50 \\
$3=$ Strong & 15 a 50 & 50 a 75 \\
$4=$ Very strong & $>50$ & $>75$ \\
\hline
\end{tabular}

Table 7. Limiting levels for impediment to mechanization (slope steepness $\times$ rockiness and/or slope steepness), proposed for the land agricultural suitability evaluation system for grapevine crops in high-altitude regions in Santa Catarina, Brazil.

\begin{tabular}{|c|c|c|c|c|c|c|c|}
\hline \multirow{2}{*}{\multicolumn{2}{|c|}{ Slope steepness }} & \multirow{3}{*}{$\begin{array}{l}\text { Relief } \\
\text { Type }\end{array}$} & \multicolumn{5}{|c|}{ Erodibility (Mg h $\mathrm{MJ}^{-1} \mathrm{~mm}^{-1}$ ) } \\
\hline & & & \multirow{2}{*}{ Null } & \multirow{2}{*}{ Mild } & \multirow{2}{*}{$\begin{array}{l}\text { Moderate } \\
\text { Limiting lev }\end{array}$} & \multirow{2}{*}{ Strong } & \multirow{2}{*}{$\begin{array}{l}\text { Very } \\
\text { strong }\end{array}$} \\
\hline Class & $\%$ & & & & & & \\
\hline A & $0-3$ & Plain & 0 & 1 & 3 & 4 & 4 \\
\hline B & $3-8$ & Slightly wavy & 1 & 2 & 4 & 4 & 4 \\
\hline $\mathrm{C}$ & $8-13$ & Moderately wavy & 2 & 3 & 4 & 4 & 4 \\
\hline $\mathrm{D}$ & $13-20$ & Wavy & 3 & 4 & 4 & 4 & 4 \\
\hline $\mathrm{E}$ & $20-45$ & Strongly wavy & 4 & 4 & 4 & 4 & 4 \\
\hline $\mathrm{F}$ & $>45$ & Mountain or Escarpment & 4 & 4 & 4 & 4 & 4 \\
\hline
\end{tabular}

Limiting Levels: 0 = Null; 1 = Mild; 2 = Moderate; 3 = Strong; 4 = Very Strong

Stoniness can be a serious problem for some crops, mainly for those of short cycle, by hinder mechanization. However, perennial crops, such as grapevine, even a moderate stoniness is not limiting for the development of the plants. Stones can be removed from the planting row in some cases, since the crop will be maintained for many years under production, and the cost of stone removal is economically viable over time.
Soil effective depth. Soil effective depth is other important limiting factor, since soils in grapevine producing regions in Santa Catarina are, in general, shallow. The classes of soil effective depth for evaluation of land suitability for grapevine production are presented in Table 8. 
Table 8. Limiting level due to soil effective depth, proposed for the land agricultural suitability evaluation system for grapevine crops in highaltitude regions in Santa Catarina, Brazil.

\begin{tabular}{lc}
\hline \multicolumn{1}{c}{ Limiting level } & Soil effective depth $\mathbf{( c m )}$ \\
\hline Null & $\geq 80$ \\
Mild & $50-80$ \\
Moderate & $25-50$ \\
Strong / Very strong & $0-25$ \\
\hline
\end{tabular}

The soil effective depth refers to the maximum depth that grapevine roots penetrate freely into the soil, in a reasonable number, without impediments, providing physical support to plants and conditions for water and nutrient absorption. In addition to the physical limiting for rooting of plants to high depths (quantity and thickness), a chemical limiting can occur due to high aluminum saturation, common below the arable layer of high-altitude soils in Santa Catarina. This factor represents impediment the root penetration, even in deep soils, and requires liming of deeper layers or application of gypsum in these areas.

Guide table and land suitability classes. The guide for agricultural suitability classification for high-altitude vineyards in Santa Catarina is presented in Table 9. This table shows the maximum limiting levels that the lands can present to each one of the six factors, to belong to the established suitability classes in the left column. The suitability classes are defined as a function of the strongest limiting level referring to any of the factors, for each management level.

Table 9. Guide table of the land agricultural suitability evaluation system, in the management levels B and C, for grapevine crops in high-altitude regions in Santa Catarina, Brazil.

\begin{tabular}{lcccccc}
\hline \multicolumn{1}{c}{ Suitability } & \multicolumn{4}{c}{ Limiting factors and limiting levels for the management levels B and C } \\
\cline { 2 - 7 } \multicolumn{1}{c}{ Class } & \multicolumn{2}{c}{ Topographic } & \multicolumn{2}{c}{ Soil Fertility } & \multicolumn{2}{c}{ Excess water } \\
\hline \multirow{3}{*}{ Good } & $\mathrm{B}$ & $\mathrm{C}$ & $\mathrm{B}$ & $\mathrm{C}$ & $\mathrm{B}$ & $\mathrm{C}$ \\
Regular & $\mathrm{N}$ & $\mathrm{N}$ & $\mathrm{N} / \mathrm{L}$ & $\mathrm{N}$ & $\mathrm{L}$ & $\mathrm{N} / \mathrm{L}$ \\
Restrict & $\mathrm{L}$ & $\mathrm{L}$ & $\mathrm{L}$ & $\mathrm{L}$ & $\mathrm{L} / \mathrm{M}$ & $\mathrm{L}$ \\
Inapt & $\mathrm{M}$ & $\mathrm{M}$ & $\mathrm{M}$ & $\mathrm{L} / \mathrm{M}$ & $\mathrm{M}$ & $\mathrm{L} / \mathrm{M}$ \\
Class & $\mathrm{F}$ & $\mathrm{F}$ & $\mathrm{F}$ & $\mathrm{F}$ & $\mathrm{F}$ & $\mathrm{F}$ \\
\hline Good & Susceptibility to erosion & Rockiness/ Stoniness & Soil effective depth \\
Regular & $\mathrm{L}$ & $\mathrm{N}$ & $\mathrm{L}$ & $\mathrm{N}$ & $\mathrm{N}$ & $\mathrm{N}$ \\
Restrict & $\mathrm{L}$ & $\mathrm{M}$ & $\mathrm{M}$ & $\mathrm{L}$ & $\mathrm{L}$ & $\mathrm{L}$ \\
Inapt & $\mathrm{M}$ & $\mathrm{L}$ & $\mathrm{M} / \mathrm{F}$ & $\mathrm{M}$ & $\mathrm{M}$ & $\mathrm{M}$ \\
\hline & $\mathrm{F}$ & $\mathrm{F}$ & $\mathrm{F}$ & $\mathrm{F}$ & $\mathrm{F}$ & $\mathrm{F}$ \\
\hline
\end{tabular}

Table 10 shows the symbology adopted to allow the presentation of the proposed agricultural suitability classification in a single map. It is composed by suitability classes and management levels, followed by numeric identification of limiting levels. 
Table 10. Symbology corresponding to classes of the land agricultural suitability evaluation system in the management levels B and C for grapevine crops in high-altitude regions in Santa Catarina, Brazil

\begin{tabular}{|c|c|c|c|c|c|c|}
\hline \multirow{2}{*}{$\begin{array}{c}\begin{array}{c}\text { Agricultural } \\
\text { suitability } \\
\text { classes }\end{array} \\
\text { Good } \\
\end{array}$} & \multicolumn{2}{|c|}{$\begin{array}{c}\text { Management } \\
\text { level }\end{array}$} & \multirow{2}{*}{$\begin{array}{c}\begin{array}{c}\text { Limiting } \\
\text { Levels }\end{array} \\
\text { Topographic factor } \\
\end{array}$} & \multirow{2}{*}{$\begin{array}{c}\text { Identification } \\
1 \\
\end{array}$} & \multirow{2}{*}{$\begin{array}{l}\text { Variable } \\
\text { Altitude } \\
\end{array}$} & \multirow{2}{*}{$\begin{array}{c}\text { Identification } \\
* \\
\end{array}$} \\
\hline & B & $\mathrm{C}$ & & & & \\
\hline Regular & $\mathrm{b}$ & c & & & Aspect & $* *$ \\
\hline Restrict & (b) & (c) & & & Slope & $* * *$ \\
\hline \multirow[t]{7}{*}{ Inapt } & - & - & Soil fertility & 2 & $\begin{array}{c}\text { Soil base } \\
\text { saturation }\end{array}$ & $*$ \\
\hline & & & & & Phosphorus & $* *$ \\
\hline & & & & & Potassium & $* * *$ \\
\hline & & & Excess water & 3 & & \\
\hline & & & Susceptibility to erosion & 4 & & \\
\hline & & & Impediments to mechanization & 5 & & \\
\hline & & & Soil effective depth & 6 & & \\
\hline
\end{tabular}

The absence of limiting factors (Table 9), will cause the area to be identified with a good land suitability class, resulting in symbolism B or C depending on the level of management. If the limitations are present in a higher degree, the area will be classified in a lower land suitability class, according to the related degree of limitation. In this case, the symbology of the aptitude class must be followed by the number of the factor that led to such a framework.

The limiting factors. (1) Topographic factor (Altitude, aspect and slope) and (2) Soil fertility (Soil base saturation, Phosphorus and Potassium) make it possible to include additional information. So the limitation can be enforced. Taking as an example a winegrower (management C), whose area has a slight deficiency (L) for soil fertility, due to the low levels of $\mathrm{P}$, the symbol in this case is $\mathrm{c} 2 *$.

Grapes used for fine wine production are grown in different soils and regions of the world. Thus, an ideal soil for grape production does not exist, but a set of ideal characteristics connected to soil for a given climate, which determine the typicity of the wine and its association to a given environment or geographical region.

Studies by Doğan and Gülser (2019) suggest that the evaluation of soil quality in vineyards may play an important role for the high productivity of the grape and Laudicina et al. (2017) reported that soil quality is one of the most important parameters that affects the production of agricultural products, being especially important in vineyards and their final products, such as grapes and wine.

Dortzbach et al. (2017) identified the need to develop a specific methodology for land agricultural suitability evaluation for highland vineyards. The areas where altitude wines are produced in Santa Catarina, Brazil, have low lad agricultural suitability for annual crops and among the limiting factors are soil fertility and slope.

Rodrigo-Comino et al. (2018), points out that soil erosion in vineyards, for example, is considered 
an environmental concern, as it decreases soil fertility and causes damage to crops and degradation downstream. The high losses of soil and water decrease the quality of the soil and, subsequently, this can reduce the quality of grapes and wine.

In this way the determination of a set of edaphic attributes serve as traits in the decision making for implementation or even enlarge vineyards, which contribute to quality wine production. Thus, the development of a specific agricultural suitability evaluation system to a crop and region is important for producers and institutions linked to agriculture and rural assistance, allowing the indication of potential areas for high-altitude viticulture.

A practical example for the application of the suitability system to grapevine is the work developed by Santos et al. (2018), who made a map of suitability for viticulture for the municipality of São Joaquim, Brazil, from multicriterial analysis of thematic physiographic maps (altitude, orientation, and slope levels) and geological/pedological maps. According to the authors, the viticulture suitability map is incipient and requires further studies to understand the complex relation between geology and pedology. Based on the work of Santos et al. (2018), the best areas for the grapevine crops (optimal class) were found in altitudes above 900 meters, presenting slopes with N orientation, with 3 and $20 \%$, and soils derived from basalts.

The result of this adaptation of the LASES to grapevine crops should be subsequently validate in field studies with grape crops of producers of management levels B and C in the state of Santa Catarina and in other high-altitude grape and wine producing regions, such as those in the state of Rio Grande do Sul, Brazil.

\section{CONCLUSIONS}

The adaptation of the land agricultural suitability evaluation system to grapevine crops grown in high-altitude conditions in the state of Santa Catarina incorporate and adjust important local aspects for the grape production system.

The proposed agricultural suitability evaluation system for grapevine crops grown in high-altitude regions in Santa Catarina is an important tool for the decision making for implementation of new vineyards, and contributes to the increase of this activity in the region.

\section{BIBLIOGRAPHIC REFERENCES}

Araújo, A.G.; Assad, M.L.L. (2001). Zoneamento pedoclimático por cultura a partir de levantamento de solos de baixa intensidade. Revista Brasileira de Ciência do Solo 25(1):103-111. doi: doi.org/10.1590/ S0100-06832001000100011

Acharya, T.D.; Yang, I.T. (2015). Vineyard suitability analysis of Nepal. International Journal Environmnet Science. 6(1):13-19. doi:10.6088/ijes.6002

Cardoso, L.S.; Bergamaschi, H.; Comiran, F.; Chavarria, G., Marodin, G.; Dalmago, G.; Santos, H.; Mandelli, F. (2010). Padrões de interceptação de radiação solar em vinhedos com e sem cobertura plástica. Revista Brasileira de Fruticultura. 32(1): 161-171. doi: doi. org/10.1590/S0100-29452010005000029

Chagas, C.S.; Carvalho Junior, W.; Pereira, N.R.; Fernandes Filho, E.I. (2006). Aplicação de um sistema automatizado (ALES - Automated Land Evaluation System) na avaliação das terras das microrregiões de Chapecó e Xanxerê, oeste catarinense, para o cultivo de grãos. Revista Brasileira de Ciência do Solo. 30(3): 509-522. doi: doi.org/10.1590/S010006832006000300012

Chen, T. (2011). Using a geographic information system to define regions of grape cultivar suitability in Nebraska. Recovered from https://digitalcommons. 
unl.edu/cgi/viewcontent.cgi?referer=https:// www.google.com/\&httpsredir $=1 \&$ article $=1009 \& \mathrm{co}$ ntext=geographythesis

Doğan, B.; Gülser, C. (2019). Assessment of soil quality for vineyard fields: A case study in Menderes District of Izmir, Turkey. Eurasian journal of soil science. 8(2): 176-183. doi: 10.18393/ejss.551874.

Dortzbach, D. (2016). Caracterização dos solos e avaliação da aptidão agrícola das regiões produtoras de vinhos finos de altitude de Santa Catarina. Recovered from https://tede.ufrrj.br/ jspui/bitstream/jspui/2066/4/2016\%20-\%20 Denilson\%20Dortzbach.pdf

Dortzbach, D.; Pereira, M.G.; Anjos, L.H.C.; González, A.P. (2017). Avaliação de áreas produtoras de vinhos finos de altitude de acordo com a sua aptidão ou potencial agrícola das terras. Agropecuária Catarinense. 30(3): 67-71.

Eduardo, E.N.; Carvalho, D.F.; Machado, R.L.; Soares, P.; Almeida, W.S. (2013). Erodibilidade, fatores cobertura e manejo e práticas conservacionistas em argissolo vermelho-amarelo, sob condições de chuva natural. Revista Brasileira de Ciência do Solo. 37(3): 796-803. doi: doi.org/10.1590/S010006832013000300026

Elsheikh, R.; Rashid, A.; Mohamed Sharif, B.; Amiri, F.; Ahmad, N.B.; Balasundram, S.K.; Soom, M. (2013). Agriculture Land Suitability Evaluator (ALSE): A decision and planning support tool for tropical and subtropical crops. Computers and Electronics in Agriculture. 93: 98-110. doi: doi.org/10.1016/j. compag.2013.02.003

Embrapa - Empresa Brasileira de Pesquisa Agropecuária. (1997). Manual de métodos de análise de solos. 2.ed. Rio de Janeiro: Embrapa. 212p.

Embrapa-Empresa BrasileiradePesquisaAgropecuária. (2013). Sistema Brasileiro de Classificação de Solos. 3.ed. Brasília: Embrapa. 353 p.

Giboshi, M.L.; Rodrigues, L.; Lombardi Neto, F. (2006). Sistema de suporte à decisão para recomendação de uso e manejo da terra. Revista Brasileira de Engenharia Agrícola e Ambiental. 10(4): 861-866. doi.org/10.1590/S1415-43662006000400012
González, F.M. (2005). Influências dos fatores edafoclimáticosnasuvasevinhosCabernetSauvignon de diferentes pólos vitícolas do Rio Grande do Sul. Recovered from http://www.dominiopublico. gov.br/pesquisa/DetalheObraForm.do?select_ action $=\&$ co_obra $=25644$

Jones, G.V.; Snead, N.; Peder, N. (2004). Geology and Wine 8: Modeling Viticultural Landscapes: A GIS Analysis of the Terroir Potential in the Umpqua Valley of Oregon. Geoscience Canada. 31(4):167178.

Lanyon, D.M.; Cass, A.; Hansen, D. (2004). The effect of soil properties on vine performance. Australia: CSIRO Land and Water.

Laudicina, V.A.; Palazzolo, E.; Catania, P.; Vallone, M.; García, A.D.; Badalucco, L. (2017). Soil quality indicators as affected by shallow tillage in a vineyard grown in a semiarid Mediterranean environment. Land Degradation Land Degradation Development and Development. 28(3):1038-1046. doi.org/10.1002/ldr.2581.

Leeuwen, C.; Tregoat, 0.; Choné, X.; Bois, B.; Pernet, D.; Gaudillère, J.P. (2009). Vine water status is a key factor in grape ripening and vintage quality for red Bordeaux wine. How can it be assessed for vineyard management purposes? Journal International des Sciences de la Vigne. 43(3): 21-134. doi: doi. org/10.20870/oeno-one.2009.43.3.798

Mafra, S.H.M.; Cassol, P.C.; Miquelluti, D.J.; Ernani, P.R.; Gatiboni, L.C.; Ferreira, E.Z.; Barros, M.; Zalamena, J.; Grohskopf, M.A. (2011). Atributos químicos do solo e estado nutricional de videira Cabernet Sauvignon (Vitis vinifera L.) na Serra Catarinense. Revista de Ciências Agroveterinárias. 10(1): 44-53.

Mota, R.V.; Regina, M.A.; Amorim, D.A.; Fávero, A.C. (2006). Fatores que afetam a maturação e a qualidade da uva para vinificação. Recovered from https://www.bdpa.cnptia.embrapa.br/ consulta $/$ busca? $\mathrm{b}=\mathrm{ad} \& \mathrm{id}=505376 \&$ biblioteca $=$ vazio\&busca=autoria:\%2 2 M0TA, $\% 20$ R.V. $\% 20$ da. $\% 22 \& q$ Facets=autoria:\%22M0TA,\%20R.V.\%20 da. $\% 22 \&$ sort $=\&$ paginacao $=t \&$ paginaAtual $=1$

Pajewski, F.F.; França, A.; Behling, A.; Jaçanan, H.; Tres, A. (2018). Efeito da altitude sobre as variáveis 
meteorológicas em um trecho de floresta ombrófila densa submontana. Biofix Scientific Journal. 3(2): 302-310. doi: dx.doi.org/10.5380/biofix. v3i2.61130

Pereira, L.C.; Lombradi Neto, F. (2004). Avaliação da aptidão agrícola das terras: proposta metodológica. Jaguariúna: Embrapa Meio Ambiente. 36p.

Ramalho Filho, A.; Beek, K.J. (1995). Sistema de avaliação da aptidão agrícola das terras. 3.ed. Rio de Janeiro: Embrapa/CNPS. 65p.

Rasheed, S.; Venugopal, K. (2009). Land suitability assessment for selected crops in Vellore district based on agro-ecological characterization. Journal of the Indian Society of Remote Sensing. 37: 615-629. doi: doi.10.1007/s12524-009-0060-4

Regina, M.A.; Fráguas, J.C.; Alvarenga, A., Souza, C.R.; Amorim, D.; Fávero, R. (2006). Implantação e manejo do vinhedo para produção de vinhos de qualidade. Informe Agropecuario. 27(234): 16-31.

Ribeiro, M.R. (2007). Metodologias de avaliação da aptidão agrícola das terras e as variáveis regionais. Anais da Academia Pernambucana Ciência Agronômica. 4:116-125.

Rigon, L.; Corrêa, S.; Reetz, E.; Rosa, G.R.; Vencato, A.; Beling, R.R. (2006). Anuário brasileiro da uva e do vinho. Santa Cruz do Sul: Gazeta Santa Cruz. 136p.

Rodrigo-Comino, J.; Keesstra, S.; Cerdà, A. (2018). Soil Erosion as an Environmental Concern in Vineyards: The Case Study of Celler del Roure, Eastern Spain, by Means of Rainfall Simulation Experiments. Beverages. 4(31): 1-12. doi:10.3390/ beverages 402003

Santos, E. A.; Florisbal, L. M.; Loss, A.; Besser, M. L.; Dortzbach, D. (2018). Geology and Wine 15. Producing Wine at Altitude: The Terroir of São Joaquim, Brazil. Geoscience Canada. 45(3/4):137149. doi: doi.10.12789/geocanj.2018.45.139

Santos,E.P.(2006).Aspectos ecofisiológicos na condução da videira e sua influência na produtividade do vinhedo e na qualidade dos vinhos. Recovered from https://www.infoteca.cnptia.embrapa.br/ bitstream/doc/541896/1/cot071.pdf
Santos, A.O.; Hernandes, J.L.; Pedro, JR.; Mario, J.; Rolim, G.S. (2011). Parâmetros fitotécnicos e condições microclimáticas para videira vinífera conduzida sob dupla poda sequencial. Revista Brasileira de Engenharia Agrícola e Ambiental. 15:1251-1256. doi: doi.org/10.1590/S1415-43662011001200006.

Sarmento, E.C.; Flores, A.; Weber, E.; Hasenack H. (2011). Vineyards and edaphic suitability for viticulture in the Vale dos Vinhedos, Brazil. Recovered from http://www.ecologia.ufrgs.br/labgeo/arquivos/ Publicacoes/Congressos/2011/Sarmento_et_ al_2011_Vineyards_and_edaphic_suitability_for_ viticulture.pdf

Souza, J.S.I. (1996). Uvas do Brasil. Piracicaba: Fealq. $791 \mathrm{p}$.

Spayd, S.E.; Tarara, J.M.; Mee, D.L.; Ferguson, J.C. (2002). Separation of sunlight and temperature effects on the composition of Vitis vinifera cv. Merlot berries. American Journal of Enology and Viticulture. 53(3): 171-181.

Tonietto, J.; Mandelli, F. (2003). Clima. In: Gilmar B. Kuhn. (Org.). Uvas Americanas e Híbridas para Processamento em Clima Temperado. Brasília: Embrapa Informação Tecnológica.

Uberti, A.; Bacic I.; Laus Neto, J.; Moser, JM.; Pundeck, M.; Carrião, S. (1991). Metodologia para classificação da aptidão de uso das terras do Estado de Santa Catarina. Florianópolis: Empasc/Acaresc. 19p.

Univibra - União Brasileira de Vitivinicultura. (2015). Manual de produção de uvas viniferas de alta qualidade. Recovered from http://www.uvibra. com.br/manual_producao_uvas_viniferas_alta_ qualidade_2015.pdf

Valeriano, M.M. (2008). Dados topográficos. In: Florenzano, TG. Geomorfologia: conceitos $e$ tecnologias atuais. pp. 72-104. São Paulo: Oficina de Textos.

Vasconcelos, V.V.; Hadad, R.M.; Martins Junior, P.P. 2013. Metodologias para estudos integrados de recursos naturais: uma discussão a partir do zoneamento ecológico-econômico. Pesquisas em geociências. 
40(1): 21-30. doi: doi.org/10.22456/18079806.40829

Vieira, R.C.B.; Bayer, C.; Fontoura, S.; Anghinoni, I.; Ernani, P.; Moraes, R.P. (2013). Critérios de calagem e teores críticos de fósforo e potássio em latossolos sob plantio direto no centro-sul do Paraná. Revista Brasileira de Ciência do Solo.37(1):188-198.https:// doi.org/10.1590/S0100-06832013000100019

Vianna, L.; Massignam, A.M.; Pandolfo, C.; Dortzbach, D.; Vieira, V. (2016) Caracterização agronômica e edafoclimática dos vinhedos de elevada altitude. Revista de Ciências Agroveterinárias. 15(3): 215226.

Wolf, T.K.; Boyer, J.D. (2003). Vineyard Site Selection. Blacksburg: Virginia Polytechnic Institute and State University. 36p.

White, R.E. (2003). Soils for fine wines. Nova York: Oxford University Press. 312p. 